\title{
CHANGES IN WOOD PROPERTIES OF CHESTNUT WOOD STRUCTURAL ELEMENTS WITH NATURAL AGING
}

\author{
Elif Topaloglu ${ }^{1, \star}$ \\ https://orcid.org/0000-0003-4736-8702 \\ Derya Ustaomer ${ }^{2}$ \\ https://orcid.org/0000-0003-0102-818X \\ Murat Ozturk ${ }^{3}$ \\ https://orcid.org/0000-0003-1405-036X \\ Emrah Pesman ${ }^{4}$ \\ https://orcid.org/0000-0003-0189-4715
}

\begin{abstract}
Knowing the effects of natural aging on wood properties is important both for the conservation of historical wooden material and for reuse of aged wood. The aim of this study was to investigate the wood properties of old wooden elements not impregnated with any protective chemicals and taken from different parts of Zeytinlik houses in Giresun, Turkey. Test samples were prepared from old wooden elements and freshly cut chestnut timber. The anatomical, chemical, physical and mechanical properties were determined according to standard procedure, and the results were compared with those of recent wood specimen. As a result of the anatomical identification, it was determined that the wooden elements used in traditional Zeytinlik houses belong to species of Anatolian chestnut (Castanea sativa), and after an average service life of 88, 113 and 120 years, there was no change in the anatomical structure of the old wooden elements. Fourier transform infrared band characterization of old wood specimens revealed that hemicelluloses degraded and lignin structure changed on the surface of almost all specimens. Especially, the wood density values of the facade elements were smaller than that of recent wood specimen. Except for the modulus of rupture of window sill and rafter, all mechanical properties were significantly greater compared with those of recent wood specimen. The results of this research showed that old wood not damaged by fungi and insects could be evaluated for reuse.
\end{abstract}

Keywords: Natural aging, service life, wood anatomy, wood properties, wooden structural elements.

\section{INTRODUCTION}

Technological development of humanity from the primitive age to the present has been closely related to human dependence on wood. Most of the properties of wood enabled it to be used both as an industrial raw material and as a construction material (Panshin and Zeeuw 1970). Wood can have a nearly unlimited service life under ideal conditions (Williams 2005). Service life is defined as "the period of time after installation

\footnotetext{
${ }^{1}$ Giresun University, Technical Sciences Vocational School, Architecture and Urban Planning Department, Giresun, Turkey.

${ }^{2}$ Karadeniz Technical University, Faculty of Forestry, Forest Industry Engineering Department, Trabzon, Turkey.

${ }^{3}$ Karadeniz Technical University, Faculty of Forestry, Forest Engineering Department, Trabzon, Turkey.

${ }^{4}$ Artvin Coruh University, Faculty of Forestry, Forest Industry Engineering Department, Artvin, Turkey.

"Corresponding author: elif.topaloglu@giresun.edu.tr
}

Received: 20.03.2020 Accepted: 16.11.2020 
during which a facility or its component parts meet or exceed the performance requirements" (ISO 15686-1 2011). The service life of wood can exceed thousands of years under conditions where the weathering and biodegradation is prevented. The main source of degradation is aging (Matsuo et al. 2011). Aging of wood is a process that starts with the cutting of a tree and depends on environmental conditions. The aging process can take place on the historical wood, archaeological wood, and fossilized wood under different conditions such as aerobic and anaerobic conditions (Fengel 1991). When unprotected wood is exposed to atmospheric conditions, its surface becomes rough and darkened (Panshin and Zeeuw 1970). Ultraviolet (UV) light, moisture, temperature, abrasion or mechanical actions are the important factors in this process, which is defined as weathering (Feist 1983).

The effect of aging on the physical and mechanical properties is frequently uncertain and depends on wood species, aging time and storage conditions (Sonderegger et al. 2015). In addition, the aging conditions, different test methods or difficulties in sample matching may have affected wood aging process. Changes in the physical and mechanical properties of wood with aging result from changes in its microstructure and chemical changes in the components (Kránitz et al. 2016). Borgin et al. (1975) investigated the mechanism of fracture of wood samples between the ages of 900 and 4400, and determined that the weakest parts of the wood structure are the middle lamella/S1 region and interfibrillar matrix. Kačík et al. (2014) observed that the cellulose in old fir wood beams samples increased by $13 \%$, both the lignin and holocellulose dropped by $4 \%$ compared to the recent fir wood. Machado et al. (2019) concluded that the density values of old wood belonging to Pinus sylvestris and Pinus pinaster with a service life of about 250 years are compatible with the value of the new wood. However, some authors reported that a decrease in the density values and various mechanical properties such as compressive strength and static bending strength for salvaged wood of Juniperus excelsa and Pinus sylvestris (Bektas et al. 2004, Bektas et al. 2005, Yorur et al. 2014).

During the service life of wood materials, which carry out functions such as beam, wall, floor, and roof element in buildings, degradation in wood properties may occur due to some factors. If the wood materials used are not impregnated with protective chemicals, the damage may be higher. It is important to determine the physical, chemical and mechanical properties of the wood materials used in order to have more information about the service life of the wood materials used in traditional wooden structures and to decide whether the wood materials can be reused. The aim of this study is to investigate the changes in wood properties of old wood materials used in traditional Giresun-Zeytinlik houses with natural aging. Moreover, it is aimed to find answers to the questions about the durability of old wood materials by comparing with the findings obtained from recent wood specimen.

\section{MATERIALS AND METHODS}

\section{Materials}

Traditional Zeytinlik houses are located in Zeytinlik District of Giresun $\left(40^{\circ} 55^{\prime}\right.$ ' north latitude $-38^{\circ} 23^{\prime}$ ' east longitude), Turkey. A total of six old wood materials were extracted from three randomly selected houses from traditional Zeytinlik houses. The approximate ages of the houses where the old wood materials were extracted can be stated as follows: 120 years for the front support, rafter and roof ridge, 113 years for the window sill and window blinds, and 88 years for the column pillar. The front support, window sill and window blinds are the structural elements that act as facade elements, the rafter and roof ridge are the roof elements, and column pillar is the carrier elements. In addition, the front support, rafter, roof ridge and column pillar are the elements that serve as load carriers in the structure. Figure 1 shows the macroscopic appearance of old wood materials used in this study. It was found macroscopically that all the old wood materials extracted from the houses were produced from the heartwood part of the tree and the sapwood part was not very common. In addition, as a result of visual inspection, there are nails on the front support, rafter and roof ridge elements; window sill and window blinds elements were exposed to UV degradation and color change was observed on their surfaces. 


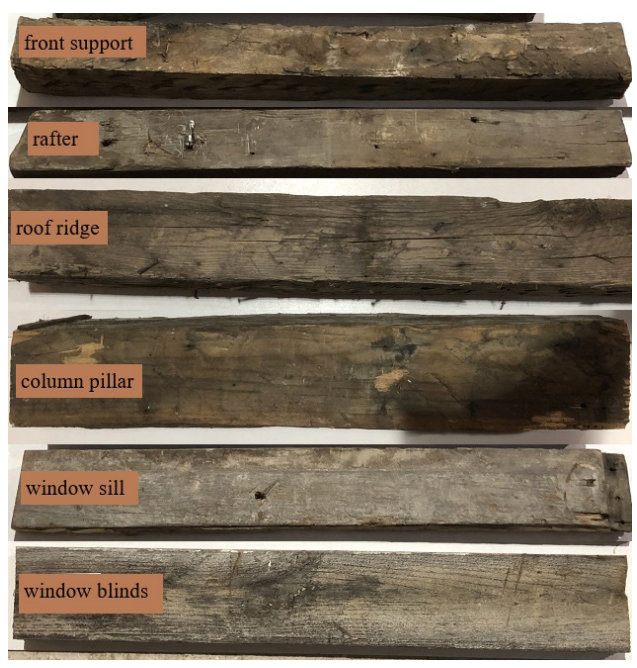

Figure 1: Macroscopic appearance of old wood materials from Zeytinlik houses.

\section{Preparation of wood specimens}

Wood specimens consist of a total of seven different wood materials, six old wood materials that were extracted from different building parts of selected houses and one wood material was obtained by cutting from recent wood. About $10 \mathrm{~cm}$ long pieces were cut in the transverse direction from the ends of each of the old wood materials. These pieces were used to determine the anatomical features of wood, FTIR-ATR (Fourier transform infrared- Attenuated total reflection) measurements, and the remaining parts were used to determine the physical and mechanical properties of wood. In order to compare the results of old wood specimens and recent wood specimens, one healthy and smooth-stem chestnut tree, 60 -years-old and with diameter of $30 \mathrm{~cm}$ at breast height $(1,30 \mathrm{~m})$, was cut. All wood samples were conditioned in the air-conditioning chamber at 20 ${ }^{\circ} \mathrm{C}$ and $65 \%$ relative humidity until they reached $12 \%$ humidity.

\section{Wood identification and determination of anatomical features}

To determine anatomical features of wood, $1 \mathrm{~cm} \times 1 \mathrm{~cm} \times 1 \mathrm{~cm}$ cubic pieces of wood were extracted from all wood materials. Three sections of transverse, radial and tangential thickness of 15 to 20 microns were taken by using Reichert slide microtome. These sections were exposed to sodium hypochlorite for 5 to 10 minutes and then washed with distilled water. Before staining of the sections, 1 to 2 drops of acetic acid were added to equilibrate the $\mathrm{pH}$ and allowed to stand for 1 to 2 minutes and washed again with distilled water. After this procedure, the sections were stained for 5 minutes in safranin 0 solution. After staining, sections were taken into $50 \%$ alcohol-water mixture. Permanent preparations were prepared by performing standard preparation procedures on the sections (Ives 2001). The microphotographs of the wood samples were taken with Olympus BX 50 digital photomicroscope and transferred to computer with Image Monitoring and Analysis System. Wood materials were identified by using comparisons method with the reference collection of the KATO (Karadeniz Technical University, Herbarium) wood collection, InsideWood database (InsideWood 2018) and Merev (1998). All anatomical descriptions conform to the IAWA Committee for microscopic features of heartwood (Wheeler et al. 1989). Wood anatomical features measured include: tangential and radial vessel diameter in early wood and late wood, vessel frequency $\left(\right.$ per $\mathrm{mm}^{2}$ ), ray height, ray width and ray frequency (per $\mathrm{mm}$ ). Thirty measurements or counts were performed for each anatomical parameter. All measurements were taken using Bs200ProP Image analyze software (BAB 2000).

\section{Fourier transform infrared (FTIR) spectroscopy analysis}

The Shimadzu IR Prestige-21 FTIR equipped with ATR (attenuated total reflection) was used to determine the characterization of the old wood materials. Fourier transform infrared spectra were recorded between 600 $\mathrm{cm}^{-1}$ and $1800 \mathrm{~cm}^{-1}$, with a resolution of $8 \mathrm{~cm}^{-1}$ and 16 scans per experiment. Spectrum scans were performed on the specimens taken from the surface part which is exposed to outdoor conditions and light radiation, and 
from the inner part which is not affected by these effects.

\section{Determination of wood density}

Density test was determined according to ISO 13061-2 (2014) standard. In order to determine wood density, small wood specimens with dimensions of $20 \mathrm{~mm} \times 20 \mathrm{~mm} \times 30 \mathrm{~mm}$ (tangential $\times$ radial $\times$ longitudinal) were cut from all wood materials. As the wood density varies according to the moisture content (MC) of wood, the density values were calculated in two different forms as oven dry $(0 \% \mathrm{MC})$ density and air-dry $(12 \%$ MC) density. Moisture content of wood specimens was determined according to ISO 13061-1 (2014) standard. Density value $\left(\mathrm{kg} / \mathrm{m}^{3}\right)$ was calculated by ratio of mass $(\mathrm{kg})$ to volume $\left(\mathrm{m}^{3}\right)$ at $0 \%$ and $12 \% \mathrm{MC}$.

\section{Determination of wood mechanical properties}

Modulus of rupture (MOR in $\mathrm{MPa}$ ) and modulus of elasticity (MOE in $\mathrm{MPa}$ ) were determined in a threepoint bending test according to ISO 13061-3 (2014) and ISO 13061-4 (2014), respectively. The measurements were performed using a Zwick universal testing machine with $20 \mathrm{~mm} \times 20 \mathrm{~mm} \times 300 \mathrm{~mm}$ (tangential $\times$ radial $\times$ longitudinal) wood specimens. The load was applied to the radial section and the middle part of wood specimens. The crosshead speed was $15 \mathrm{~mm} / \mathrm{min}$ and span length was $240 \mathrm{~mm}$. For compression strength parallel to grain test, small wood specimens with dimensions of $20 \mathrm{~mm} \times 20 \mathrm{~mm} \times 30 \mathrm{~mm}$ (tangential $\times$ radial $\times$ longitudinal) were used. Compression test was carried out according to ISO 13061-17 (2014) standard using a Zwick universal testing machine with a crosshead speed of $10 \mathrm{~mm} / \mathrm{min}$.

\section{Statistical analysis}

Moisture content, wood density and mechanical properties of old and recent wood specimens were tested by One Way Anova test the basis of the $95 \%$ confidence interval. Significant differences between the groups were determined by Duncan homogeneity groups. Statistical analysis was performed using the SPSS 22.0 program (IBM 2020).

\section{RESULTS AND DISCUSSION}

\section{Wood identification}

The old wood materials from traditional Zeytinlik houses were identified microscopically to Castanea sativa Mill. (chestnut wood). Microscopic photographs of three sections of old and recent wood specimens were shown in Figure 2, Figure 3 and Figure 4.

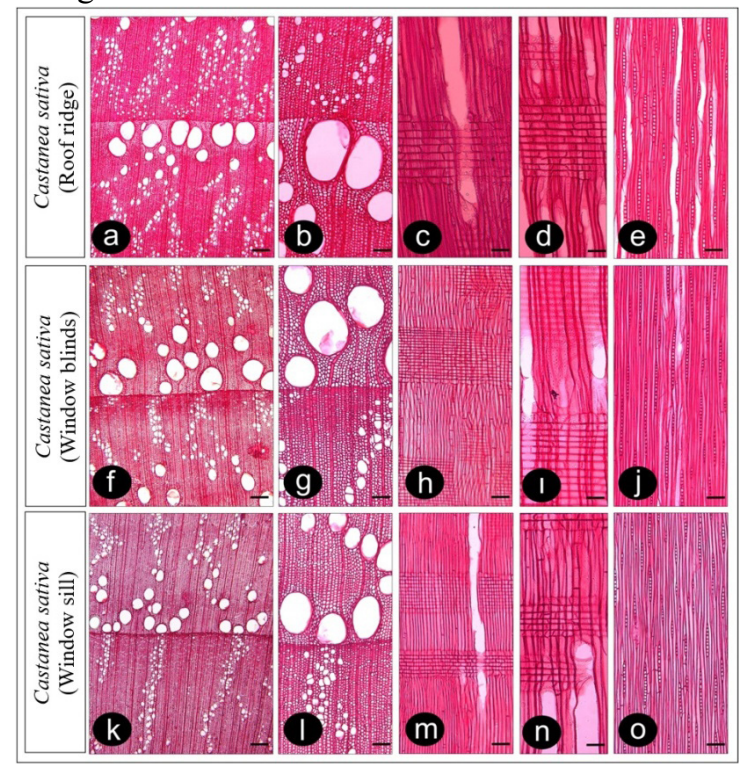

Figure 2: Microscopic photographs of the wood anatomy of Castanea sativa Mill. used as the roof ridge, window blinds and window sills in traditional Zeytinlik houses.

(a-b, f-g, k-l: transverse section, c-d, h-1, m-n: radial section, e, j, o: tangential section.

- Scale bar for a, f, $\mathrm{k}=250 \mu \mathrm{m}$, for $\mathrm{b}, \mathrm{c}, \mathrm{e}, \mathrm{g}, \mathrm{h}, \mathrm{j}, \mathrm{l}, \mathrm{n}, \mathrm{o}=100 \mu \mathrm{m}$, for $\mathrm{d}, \mathrm{1}, \mathrm{n}=50 \mu \mathrm{m}$ ). 


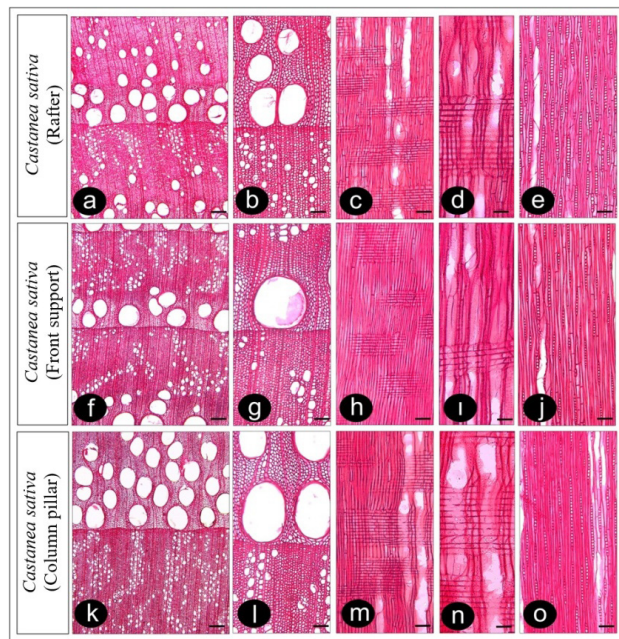

Figure 3: Microscopic photographs of the wood anatomy of Castanea sativa Mill. used as rafter, front support and column pillar in traditional Zeytinlik houses.

(a-b, f-g, k-l: transverse section, c-d, h-1, m-n: radial section, e, j, o: tangential section.,

- Scale bar for a, f, $\mathrm{k}=250 \mu \mathrm{m}$, for $\mathrm{b}, \mathrm{c}, \mathrm{e}, \mathrm{g}, \mathrm{h}, \mathrm{j}, 1, \mathrm{~m}, \mathrm{o}=100 \mu \mathrm{m}$, for $\mathrm{d}, \mathrm{i}, \mathrm{n}=50 \mu \mathrm{m}$ ).

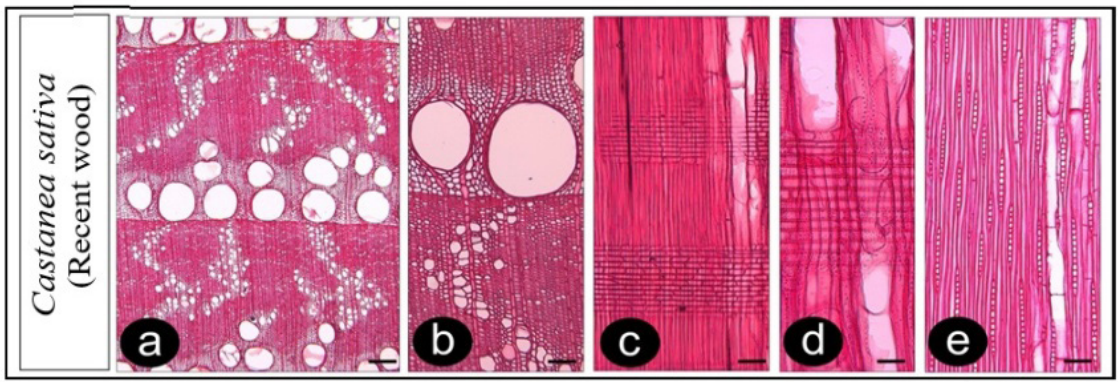

Figure 4: Microscopic photographs of the wood anatomy of Castanea sativa Mill. was obtained from recent wood specimen.

(a-b: transverse section, c-d: radial section, e: tangential section.,

- Scale bar for $\mathrm{a}=250 \mu \mathrm{m}$, for $\mathrm{b}, \mathrm{c}, \mathrm{e}=100 \mu \mathrm{m}$, for $\mathrm{d}=50 \mu \mathrm{m})$.

Its wood is ring-porous and growth rings boundaries are distinct. Vessels are arranged in diagonal and/or radial pattern. The apotracheal axial parenchyma is diffuse and paratracheal axial parenchyma is occasionally scanty (Figure 2, Figure 3 a, b, f, g, k, 1 and Figure 4 a, b). Vessel elements have a simple perforation plate. Homocellular rays cells are exclusively procumbent (Figure 2, Figure $3 \mathrm{c}, \mathrm{d}, \mathrm{h}, \mathrm{i}, \mathrm{m}, \mathrm{n}$ and Figure $4 \mathrm{c}, \mathrm{d}$ ). Rays are exclusively uniseriate (Figure 2, Figure $3 \mathrm{e}, \mathrm{j}$, o and Figure $4 \mathrm{e}$ ). Average values of anatomical features of old and recent wood specimens are given in Table 1.

Table 1: Average values of anatomical features of old and recent wood specimens.

\begin{tabular}{|c|c|c|c|c|c|c|c|c|c|}
\hline \multirow{2}{*}{\multicolumn{3}{|c|}{ Anatomical features }} & \multicolumn{6}{|c|}{ Old wood specimens } & \multirow{2}{*}{$\begin{array}{c}\text { Recent } \\
\text { wood } \\
\text { specimen }\end{array}$} \\
\hline & & & \multirow{2}{*}{\begin{tabular}{|c|}
$\begin{array}{c}\text { Roof } \\
\text { ridge }\end{array}$ \\
164,53 \\
$(34,53)^{* *}$
\end{tabular}} & \multirow{2}{*}{$\begin{array}{c}\begin{array}{c}\text { Window } \\
\text { blinds }\end{array} \\
199,32 \\
(48,50)\end{array}$} & \multirow{2}{*}{$\begin{array}{c}\begin{array}{c}\text { Window } \\
\text { sill }\end{array} \\
136,21 \\
(19,75)\end{array}$} & \multirow{2}{*}{$\begin{array}{l}\text { Rafter } \\
219,52 \\
(33,44)\end{array}$} & \multirow{2}{*}{$\begin{array}{c}\begin{array}{c}\text { Front } \\
\text { support }\end{array} \\
246,15 \\
(37,05)\end{array}$} & \multirow{2}{*}{$\begin{array}{c}\begin{array}{c}\text { Column } \\
\text { pillar }\end{array} \\
247,95 \\
(20,03)\end{array}$} & \\
\hline \multirow{5}{*}{$\begin{array}{l}\bar{\Phi} \\
\overline{8} \\
\bar{\nu}\end{array}$} & $\overline{0}$ & $\begin{array}{l}\text { VTD } \\
(\mu \mathrm{m})\end{array}$ & & & & & & & $\begin{array}{l}209,30 \\
(39,14)\end{array}$ \\
\hline & 론 & $\begin{array}{l}\text { VRD } \\
(\mu \mathrm{m})\end{array}$ & $\begin{array}{c}189,01 \\
(47,28)\end{array}$ & $\begin{array}{l}226,38 \\
(47,38)\end{array}$ & $\begin{array}{l}161,83 \\
(18,65)\end{array}$ & $\begin{array}{l}251,54 \\
(40,35)\end{array}$ & $\begin{array}{l}279,85 \\
(29,18)\end{array}$ & $\begin{array}{l}322,58 \\
(29,82)\end{array}$ & $\begin{array}{l}223,39 \\
(45,71)\end{array}$ \\
\hline & \multirow{2}{*}{$\begin{array}{l}\bar{\Xi} \\
\vdots \\
\vdots \\
\text { ज्ञ }\end{array}$} & $\begin{array}{l}\text { VTD } \\
(\mu \mathrm{m})\end{array}$ & $\begin{array}{l}30,74 \\
(3,86)\end{array}$ & $\begin{array}{l}41,32 \\
(3,56)\end{array}$ & $\begin{array}{l}35,30 \\
(5,02)\end{array}$ & $\begin{array}{c}37,57 \\
(6)\end{array}$ & $\begin{array}{l}35,24 \\
(4,88)\end{array}$ & $\begin{array}{l}41,44 \\
(7,74)\end{array}$ & $\begin{array}{l}42,31 \\
(7,16)\end{array}$ \\
\hline & & $\begin{array}{l}\text { VRD } \\
(\mu \mathrm{m})\end{array}$ & $\begin{array}{l}32,58 \\
(3,74)\end{array}$ & $\begin{array}{l}49.86 \\
(5,41)\end{array}$ & $\begin{array}{l}39,34 \\
(5,91)\end{array}$ & $\begin{array}{l}37,58 \\
(6,38)\end{array}$ & $\begin{array}{l}39,28 \\
(5,99)\end{array}$ & $\begin{array}{l}53,74 \\
(3,82)\end{array}$ & $\begin{array}{l}49,45 \\
(8,01)\end{array}$ \\
\hline & \multicolumn{2}{|c|}{$\begin{array}{l}\text { Frequency } \\
\left(\text { per } \mathrm{mm}^{2}\right)\end{array}$} & $\begin{array}{l}36 \\
(2)\end{array}$ & $\begin{array}{l}32 \\
(3)\end{array}$ & $\begin{array}{l}25 \\
(2)\end{array}$ & $\begin{array}{l}35 \\
(4)\end{array}$ & $\begin{array}{l}24 \\
(2)\end{array}$ & $\begin{array}{l}32 \\
(1)\end{array}$ & $\begin{array}{l}28 \\
(6)\end{array}$ \\
\hline \multirow{3}{*}{ 突 } & \multicolumn{2}{|c|}{ Height $(\mu \mathrm{m})$} & $\begin{array}{l}239,68 \\
(20,51)\end{array}$ & $\begin{array}{l}281,83 \\
(51,75)\end{array}$ & $\begin{array}{l}204,41 \\
(30,30)\end{array}$ & $\begin{array}{l}253,88 \\
(39,37)\end{array}$ & $\begin{array}{l}185,72 \\
(30,18)\end{array}$ & $\begin{array}{l}250,79 \\
(34,48)\end{array}$ & $\begin{array}{l}266,10 \\
(36,68)\end{array}$ \\
\hline & \multicolumn{2}{|c|}{ Width $(\mu \mathrm{m})$} & $\begin{array}{l}15,85 \\
(1,65)\end{array}$ & $\begin{array}{l}11,82 \\
(0,83)\end{array}$ & $\begin{array}{l}13,98 \\
(1,82)\end{array}$ & $\begin{array}{l}19,12 \\
(2,21)\end{array}$ & $\begin{array}{l}14,79 \\
(1,69)\end{array}$ & $\begin{array}{l}12,19 \\
(1,36)\end{array}$ & $\begin{array}{l}15,08 \\
(1,37)\end{array}$ \\
\hline & \multicolumn{2}{|c|}{$\begin{array}{c}\text { Frequency } \\
\text { (per } \mathrm{mm} \text { ) }\end{array}$} & $\begin{array}{c}8 \\
(1)\end{array}$ & $\begin{array}{c}9 \\
\text { (1) }\end{array}$ & $\begin{array}{c}8 \\
\text { (1) }\end{array}$ & $\begin{array}{l}10 \\
(1)\end{array}$ & $\begin{array}{c}9 \\
\text { (1) }\end{array}$ & $\begin{array}{l}10 \\
\text { (1) }\end{array}$ & $\begin{array}{c}9 \\
(1)\end{array}$ \\
\hline
\end{tabular}

"VTD: vessel tangential diameter, VRD: vessel radial diameter.

** Standard deviation is indicated in parentheses. 
As shown in Table 1, VTD of old wood specimens was found to be 136,21 $\mu \mathrm{m}-247,95 \mu \mathrm{m}$ and 30,74 $\mu \mathrm{m}-41,44 \mu \mathrm{m}$ for early wood and late wood, and VRD of old wood specimens was found to be $161,83 \mu \mathrm{m}$ $322,58 \mu \mathrm{m}$ and $32,58 \mu \mathrm{m}-53,74 \mu \mathrm{m}$ for early wood and late wood, respectively. VRD of both early wood and late wood were wider than VTD. Vessel diameters of early wood and late wood of recent wood specimen were found to be close to vessel diameters of the window blinds element. It was determined that vessel frequency in $1 \mathrm{~mm}^{2}$ of old wood specimens varied between 24 to 36 and this value of recent wood specimen was 28 . The ray height and width of old wood specimens ranged between $185,72 \mu \mathrm{m}-281,83 \mu \mathrm{m}$ and $11,82 \mu \mathrm{m}-19,12$ $\mu \mathrm{m}$, respectively. The number of ray per millimeter of old wood specimens was found to range between 8 to 10 , and number of ray per millimeter of recent wood specimen was found to be the same as those window blinds and front support. In this study, the results of the anatomical features of both old and recent chestnut wood were found to be consistent with the results reported by Merev (2003). As a result of natural aging and after a service life of 88,113 and 120 years, microphotographs also support that there is no change in the wood anatomy features of old wooden elements. Madhoushi (2016) reported that the wood species of structural elements removed from a historical building in Gorgan, Iran were identified as elm, lime tree, oak, sugar maple and scots pine. Dogu et al. (2017) determined that the wood of a very old timber building element that was used on the inside of a balcony and exposed to outdoor conditions for more than 400 years belongs to oak wood. They also stated that oak wood species is characterized by high durable heartwood since it contains high amount of tannins. Han et al. (2019) determined that the wood blocks taken from the beam of a historical building, which was first built in 1370 A.C., belong to the elm wood (Ulmus sp.) and they observed significant structural differences between sound aged wood.

\section{FTIR-ATR spectra analysis}

The FTIR spectra measured from the inner and surface parts of old wood specimens are given in Figure 5. The spectrum represented by blue is measured from the inner part of old wood specimens, and the spectrum represented by red is measured from the surface part of old wood specimens. It is seen in Figure 5 that there are differences between the peaks obtained from the surface parts of old wood specimens and those obtained from the inner parts. When we examined all the spectra in detail, it was observed that the peak in the $1732 \mathrm{~cm}^{-1}$ band in the specimens taken from the inner part of the wood material was lost for almost all structural elements in the spectra measured from the surface part of the specimens. The peak in this wave number is associated with carbohydrates (Marchessault and Liang 1962). The reason for the reduction of this peak in specimens exposed to light and outdoor weather conditions can be explained by the breakdown of acetyl groups in the xylan and degradation of hemicelluloses (Esteves et al. 2013). It was determined that the intensity of aforementioned peaks either decreased or disappeared completely in the spectra measured from the surface part of most structural elements. The decrease in these bands can be explained by aging and deacetilization on the surface of the wood material (Mohebby 2008, Stefke et al. 2008). Similar results were determined by Tintner et al. (2016), and also observed in a study on fossil Sequoiadendron giganteum wood performed by Uçar et al. (2005). In the measurements made from inner parts, the peak of $1596 \mathrm{~cm}^{-1}$ for roof ridge, front support, rafter, column pillar and window blinds disappeared with aging in the measurements made from surface parts, and a rather distinct new peak formed in $1643 \mathrm{~cm}^{-1}$. 

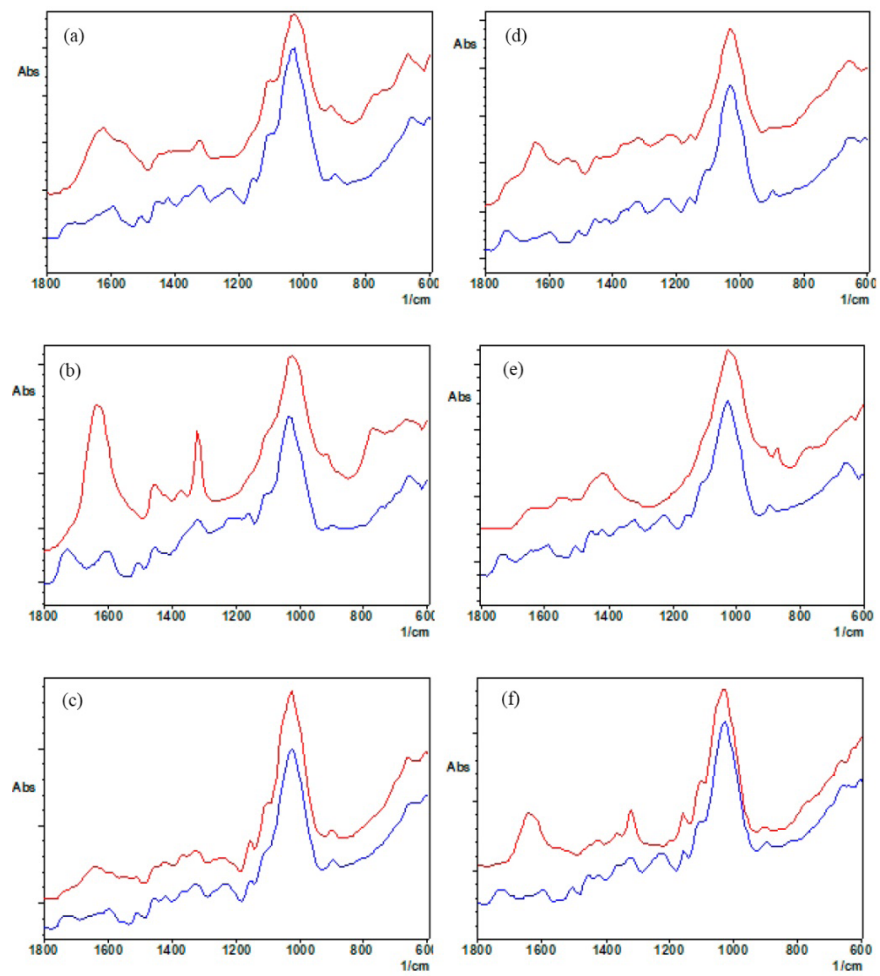

Figure 5: ATR-FTIR spectra for inner surface (blue line) and outer surface (red line) of old wood specimens ((a) front support, (b) rafter, (c) roof ridge, (d) column pillar, (e) window sill, (f) window blinds).

According to these findings, it can be said that the structure of lignin and phenolic structures changed completely with light radiation and oxidation. The conjugation degree of lignin and multiple conjugated systems increased in aged wood samples due to oxidation and decreased acid soluble lignin (Borgin et al. 1975). It is possible to conclude that the disappearance of the peak in the $1505 \mathrm{~cm}^{-1}$ band with aging supports these results. It was determined that the peak at $1318 \mathrm{~cm}^{-1}$ band became evident in the spectra of the rafter and window blinds specimens. This peak indicates the C-H vibration in cellulose (Müller et al. 2009, Guo et al. 2018). However, the peak at $1367 \mathrm{~cm}^{-1}$ had become more pronounced with the aging effect in some structural elements. The prominence in this peak was attributed to $\mathrm{CH}$ deformation in cellulose and hemicelluloses after aging (Liu et al. 2017, Tarmian and Mastouri 2019). However, during outdoor weathering, water mechanically corrodes the surface of wood material and hydrolyzes hemicelluloses on the surface, and the hemicelluloses become more vulnerable when lignin breaks down (Williams 2005).

\section{Density values}

Average values of moisture content and density of old and recent wood specimens are shown in Table 2. Fluctuations in the amount of water present in the wood considerably affect all the physical properties of wood, mechanical as well as nonmechanical (Panshin and Zeeuw 1970). As shown in Table 2, moisture content was found to be $11,69 \%$ to $13,58 \%$ and $14,54 \%$ for old wood specimens and recent wood specimen, respectively. According to One Way Anova test results; there were statistically significant differences $(\mathrm{P}=$ significance level $=0,000$ ), which are indicated in Table 2 by letters from a to e, between moisture content values of all wood specimens. The lowest moisture content was obtained in the wood specimens of roof ridge. Recent wood specimen had higher moisture content than old ones. Yokoyama et al. (2009) determined that equilibrium moisture content tends to decrease with age. Sonderegger et al. (2015) reported that the moisture content of aged oak wood at different relative humidity was lower than that of the recent wood. The decrease in amorphous cellulose or adsorption sites in hemicelluloses resulting in lower equilibrium moisture content values (Inagaki et al. 2008, Kránitz et al. 2016) may be the reason for this change in humidity of old wood specimens. 
Table 2: Average values of moisture content and density of old and recent wood specimens.

\begin{tabular}{|c|c|c|c|}
\hline Wood specimens & $\begin{array}{c}\text { Moisture content } \\
(\%)\end{array}$ & $\begin{array}{c}\text { Air-dry density } \\
\left(\mathrm{kg} / \mathrm{m}^{3}\right)\end{array}$ & $\begin{array}{c}\text { Oven dry density } \\
\left(\mathrm{kg} / \mathrm{m}^{3}\right)\end{array}$ \\
\hline Roof ridge & $11,69^{\mathrm{a}^{*}}(0,99)^{\mathrm{k} *}$ & $570^{\mathrm{d}}(20)$ & $540^{\mathrm{d}}(20)$ \\
\hline Window blinds & $13,09^{\mathrm{c}}(0,83)$ & $540^{\mathrm{c}}(20)$ & $510^{\mathrm{b}}(10)$ \\
\hline Window sill & $13,40^{\mathrm{cd}}(0,70)$ & $500^{\mathrm{a}}(20)$ & $470^{\mathrm{a}}(20)$ \\
\hline Rafter & $13,58^{\mathrm{d}}(0,76)$ & $580^{\mathrm{e}}(20)$ & $540^{\mathrm{d}}(20)$ \\
\hline Front support & $13,49^{\mathrm{cd}}(0,64)$ & $530^{\mathrm{b}}(10)$ & $500^{\mathrm{b}}(10)$ \\
\hline Column pillar & $12,54^{\mathrm{b}}(0,37)$ & $570^{\mathrm{d}}(30)$ & $530^{\mathrm{c}}(30)$ \\
\hline $\begin{array}{c}\text { Recent wood } \\
\text { specimen }\end{array}$ & $14,54^{\mathrm{e}}(0,96)$ & $570^{\mathrm{d}}(10)$ & $530^{\mathrm{c}}(10)$ \\
\hline
\end{tabular}

*The superscript letters in each column indicate a significant difference between the groups $(\mathrm{p}=0,000)$

${ }^{* *}$ Standard deviation is indicated in parentheses.

Our range of air-dry density was $500 \mathrm{~kg} / \mathrm{m}^{3}-580 \mathrm{~kg} / \mathrm{m}^{3}$ and of oven dry density was $470 \mathrm{~kg} / \mathrm{m}^{3}-540 \mathrm{~kg} / \mathrm{m}^{3}$ for old wood specimens. As seen in Table 2, the density values were found for the recent wood are among these values. According to One Way Anova test results; there were statistically significant differences $(p=0,000)$, which are indicated in Table 2 by letters from a to e for air-dry density and from a to d for oven dry density, between density values of all wood specimens. The smallest density values were found in the wood specimens of window sill, while the greatest density values were determined in the wood specimens of rafter. In a study prepared by Ay and Şahin (2002a) air-dry and oven dry density values of chestnut wood (Castanea sativa) were reported to be as $540 \mathrm{~kg} / \mathrm{m}^{3}$ and $510 \mathrm{~kg} / \mathrm{m}^{3}$, respectively. Compared with the density values of old wood specimens, the air-dry and oven dry density values of recent wood specimens were greater than the values of the front support, window sill and window blinds wood specimens, on the other hand; density values of rafter, roof ridge and column pillar wood specimens gave the same and/or close results with the values of the recent wood. According to these results, it is possible to say that there is no decrease in density values of the rafter, roof ridge and column pillar structure elements until the present day during the natural aging. Contrary to this result, window sill, window blinds and front support elements may be smaller in density values because they are the facade elements of the building and exposed to outdoor weathering effects. However, some researchers are reported that the good correlation between wood density and the erosion rate occurring on the wood surface during weathering (Feist and Mraz 1978, Williams 2005). Han et al. (2019) reported that the decrease of carbohydrates and concentration of lignin in the fiber wall after aging may lead to lower rigidity, and a decrease of density and elastic modulus of the cell wall. Furthermore, Thaler et al. (2014) found that density value of old chestnut pole with a service life of approximately 35 years and density value of recent chestnut wood as 571 $\mathrm{kg} / \mathrm{m}^{3}$ and $607 \mathrm{~kg} / \mathrm{m}^{3}$, respectively.

\section{Mechanical properties}

In the literature, there are many studies on mechanical properties of aged wood, especially compression strength, bending strength and Young's modulus. Table 3 shows the results of mechanical tests of old and recent wood specimens. Compression strength, MOR and MOE values were found to be between 51,41 MPa - 87,35 MPa, 56,09 MPa - 95,49 MPa and 7812,37 MPa - 10762,67 MPa for aged wood specimens, and 51,02 $\mathrm{MPa}, 66,11 \mathrm{MPa}, 7235,33 \mathrm{MPa}$ for recent wood specimen, respectively. The average of compression strength and MOR values of chestnut (Castanea sativa) wood are reported as $58,19 \mathrm{~N} / \mathrm{mm}^{2}$ and $79 \mathrm{~N} / \mathrm{mm}^{2}$, respectively (Ay and Şahin 2002b). One Way Anova test results showed that there were statistically significant differences $(\mathrm{p}=0,000)$, which are shown in Table 3 by letters from a to e, between compression strength values of all wood specimens. It was determined that the wood specimens of column pillar and rafter were in the same homogeneity group with recent wood specimen, and compression strength values of the other old wood specimens were greater than that of recent wood specimen. This result may be due to the fact that column pillar in structures and rafter in roofs are used as a conventional bearing elements and these elements are faced with compression and bending load, respectively. Decreases in compression strength compared with control wood were reported for salvaged juniper wood by Bektas et al. (2004), for salvaged scots pine wood by Bektas et al. (2005) and for salvaged scotch pine wood by Yorur et al. (2014). In addition, Sousa et al. (2014) found that the compression strength parallel to grain of decayed sweet chestnut beam decreased by $33,1 \%$. Furthermore, Thaler and Humar (2013) found that the compressive strength of oak and beech wooden beams used more than 100 years no changed compared to control oak wood, but it decreased for old beech wood. 
Table 3: Average values of mechanical properties of old and recent wood specimens.

\begin{tabular}{|c|c|c|c|}
\hline Wood specimens & $\begin{array}{c}\text { Compression strength } \\
(\mathrm{MPa})\end{array}$ & $\begin{array}{c}\text { MOR } \\
(\mathrm{MPa})\end{array}$ & $\begin{array}{c}\text { MOE } \\
(\mathrm{MPa})\end{array}$ \\
\hline Roof ridge & $87,35^{\mathrm{e}^{*}}(3,08)^{* *}$ & $95,49^{\mathrm{f}}(4,20)$ & $10762,67^{\mathrm{e}}(608,79)$ \\
\hline Window blinds & $70,48^{\mathrm{d}}(4,52)$ & $85,60^{\mathrm{e}}(4,80)$ & $9026,78^{\mathrm{c}}(397,93)$ \\
\hline Window sill & $61,19^{\mathrm{c}}(1,43)$ & $56,09^{\mathrm{a}}(2,70)$ & $7833,33^{\mathrm{b}}(547,05)$ \\
\hline Rafter & $53,08^{\mathrm{a}}(3,11)$ & $59,12^{\mathrm{b}}(3,48)$ & $7812,37^{\mathrm{b}}(406,41)$ \\
\hline Front support & $58,17^{\mathrm{b}}(3,12)$ & $73,50^{\mathrm{d}}(3,65)$ & $8781,33^{\mathrm{c}}(423,47)$ \\
\hline Column pillar & $51,41^{\mathrm{a}}(3,05)$ & $86,94^{\mathrm{e}}(3,14)$ & $9365,33^{\mathrm{d}}(411,60)$ \\
\hline $\begin{array}{c}\text { Recent wood } \\
\text { specimen }\end{array}$ & $51,02^{\mathrm{a}}(1,57)$ & $66,11^{\mathrm{c}}(3,77)$ & $7235,33^{\mathrm{a}}(347,17)$ \\
\hline
\end{tabular}

*The superscript letters in each column indicate a significant difference between the groups $(\mathrm{p}=0,000)$

${ }^{* *}$ Standard deviation is indicated in parentheses.

The effect of natural aging on MOR and MOE is summarized in Table 3. One Way Anova test results indicated that there were statistically significant differences $(p=0,000)$ between MOR and MOE values of wood specimens. It was determined that MOR values of rafter and window sill are smaller than that of recent wood specimen. When evaluated in terms of its use in the building among the old wooden elements in this study, the wooden element most exposed to bending is the rafter. For this reason, it is thought that the resistance of the rafter element to withstand an average bending load of 120 years gradually decreased over time. However, it was reported by Panshin and Zeeuw (1970) that the high flexural rigidity of wood is most effective in building elements such as beams. Window sill, which is among the facade elements in wooden structures, is one of the most exposed elements to outside weather conditions such as rain, snow, wind, and sun rays. Changes/ decreases in chemical components of wood as a result of both outdoor weathering and natural aging may cause weakening of mechanical resistance of wood samples. However, as the hemicellulose is deteriorated, the woody cell wall begins to collapse and loss of strength occurs (Nilsson and Rowell 2012). MOR values of the front support, column pillar, roof ridge and window blinds were quite great compared to recent wood specimen, and also MOE values all old wood specimens were greater than that of recent wood specimen. According to these results, it is possible to say that the mechanical strength performance of these wooden elements during the natural aging period is very good. This result is attributed to the natural durability and sufficient strength of chestnut wood, which is an important source of tannin. However, Emmerich et al. (2019) stated that anatomical properties of wood had an important effect on the structural integrity of hardwoods. Vurdu et al. (2013) reported no significant difference in bending strength of antique pine and antique fir woods which are approximately 100 years old, compared to control samples, and modulus of elasticity of antique pine wood was higher than control pine sample, while an inverse result was obtained for antique fir wood. Sonderegger et al. (2015) found that the bending MOR and MOE values of aged spruce wood from historical buildings were higher than that of recent wood, and they also found a contradictory result for aged fir wood. Madhoushi (2016) determined that the mechanical properties of old structural members, and concluded that these old members were structurally good despite their appearance and may be kept for reuse. Furthermore, Thaler and Humar (2013) determined that the MOR and MOE of oak and beech wooden beams, which were used more than 100 years, no deteriorated with minor differences compared to control oak wood, but both values decreased significantly for old beech wood. In another study, Thaler et al. (2014) determined MOR and MOE values as 113,5 MPa and $9379 \mathrm{MPa}$, and 94,5 $\mathrm{MPa}$ and 6708,6 MPa for old chestnut wood and recent chestnut wood, respectively. Yokoyama et al. (2009) investigated the change in mechanical properties of Hinoki (Chamaecyparis obtusa) wood taken from historical Japanese houses over time. They observed that no significant change in longitudinal and radial rigidity and longitudinal strength.

\section{CONCLUSIONS}

The old wood specimens from the Zeytinlik houses were identified as Castanea sativa (chestnut wood), one of the native tree species grown in the Black Sea region of Turkey. As a result of the anatomical identification, it was determined that there was no change in the anatomical structure of old wooden elements after average service life of 88, 113 and 120 years. However, according to results of the FTIR-ATR spectra of old wooden elements, it was determined that hemicelluloses deteriorated and the structure of lignin changed on the surface part of almost all old wood specimens. There was a decrease especially in wood density values of the facade elements depending on the time. However, the mechanical strength performance of the chestnut wooden elements used in Zeytinlik houses are generally in good condition compared to recent chestnut wood specimen. Based on these results, it was concluded that these wooden elements, which are thought to be old in appearance, are structurally in good condition and can be evaluated for reuse. It is recommended to encourage the reuse of old wooden elements, which is thought to be unusable and disposed only by looking at its external appearance. 


\section{ACKNOWLEDGEMENTS}

This study was supported by Giresun University Scientific Research Projects Coordination Unit (Project number: FEN-BAP-A-230218-46). The authors would like to thank Giresun University Scientific Research Projects Coordination Unit for its support.

\section{REFERENCES}

Ay, N.; Şahin, H. 2002a. Physical properties of Chestnut (Castanea sativa Mill.) wood obtained from Maçka-Çatak region. Artvin Çoruh University Journal of Forest Faculty 3(1): 63-71. http://ofd.artvin.edu.tr/en/pub/issue/2251/29654.

Ay, N.; Şahin, H. 2002b. Some mechanical properties of chestnut (Castanea sativa Mill.) Wood obtained from Maçka-Çatak region. Artvin Çoruh University Journal of Forest Faculty 3(1): 87-95. http://ofd.artvin.edu.tr/en/pub/issue/2251/29657.

BAB. 2000. Bs200 Pro Image System Software ISO 9001:2000. http://www.bab.com.tr/prgdis.php?prog id $=$ bs 200 doc $\&$ dilsec $=1$

Bektas, I.; Alma, M.H.; Goker, Y.; As, N.; Erdas, O. 2004. Effect of 180 years of service on various physical and mechanical properties of salvaged Crimean juniper wood. Forest Prod J 54(12): 217-219. http://eds.b.ebscohost.com/eds/pdfviewer/pdfviewer?vid=0\&sid=508ea992-ce44-4963-b65a$07 \mathrm{f} 584911 \mathrm{~b} 4 \mathrm{a} \% 40 \mathrm{pdc}-\mathrm{v}$-sessmgr06

Bektas, I.; Alma, M.H.; As, N. 2005. The effect of 120 years of service on various physical and mechanical properties of Scots pine wood used as roof beam. Wood Res-Slovakia 50(1): 27-32. https://www.researchgate.net/profile/Ibrahim_Bektas/publication/288825229

Borgin, K.; Faix, O.; Schweers, W. 1975. The effect of aging on lignins of wood. Wood Sci Technol 9(3): 207-211. https://doi.org/10.1007/bf00364638

Dogu, D.; Yilgör, N.; Mantanis, G.; Tuncer, F.D. 2017. Structural evaluation of a timber construction element originating from the great metéoron monastery in Greece. BioResources 12(2): 2433-2451. https://doi.org/10.15376/biores.12.2.2433-2451

Emmerich, L.; Wülfing, G.; Brischke, C. 2019. The Impact of Anatomical Characteristics on the Structural Integrity of Wood. Forests 10(2). https://doi.org/10.3390/f10020199

Esteves, B.; Velez Marques, A.; Domingos, I.; Pereira, H. 2013. Chemical changes of heat treated pine and eucalypt wood monitored by FTIR. Maderas-Cienc Tecnol 15(2): 245-258. https://doi.org/10.4067/s0718$221 \times 2013005000020$

Feist, W.C.; Mraz, E.A. 1978. Comparison of outdoor and accelerated weathering of unprotected softwoods. Forest Prod J 28(3): 38-43.

Feist, W.C. 1983. Weathering and protection of wood. In Proceedings of the Seventy-ninth Annual Meeting of the American Wood-Preservers' Association, 17-20 April, Kansas City, MO. Stevensville, 79: 195205.

Fengel, D. 1991. Aging and fossilization of wood and its components. Wood Sci Technol 25(3):153-177. https://doi.org/10.1007/bf00223468

Guo, J.; Zhou, H.; Stevanic, J.S.; Dong, M.; Yu, M.; Salmén, L.; Yin, Y. 2018. Effects of ageing on the cell wall and its hygroscopicity of wood in ancient timber construction. Wood Sci Technol 52(1): 131-147. https://doi.org/10.1007/s00226-017-0956-z

Han, L.; Wang, K.; Wang, W.; Guo, J.; Zhou, H. 2019. Nanomechanical and Topochemical Changes in Elm Wood from Ancient Timber Constructions in Relation to Natural Aging. Materials 12(5): https://doi.org/10.3390/ma12050786

IBM. 2020. SPSS Statistics Version 22.0. https://www.ibm.com/support/pages/spss-statistics-220-avail- 
able-download

Inagaki, T.; Yonenobu, H.; Tsuchikawa, S. 2008. Near-infrared spectroscopic monitoring of the water adsorption/desorption process in modern and archaeological wood. Appl Spectrosc 62(8): 860-865. https://doi.org/10.1366/000370208785284312

InsideWood. 2018. The InsideWood Database. http://insidewood.lib.ncsu.edu/search?3

ISO. 2014. Physical and mechanical properties of wood - Test methods for small clear wood specimens Part 1: Determination of moisture content for physical and mechanical tests. ISO 13061-1. 2014. ISO: Geneva, Switzerland. ISO. 2014. Physical and mechanical properties of wood - Test methods for small clear wood specimens - Part 2: Determination of density for physical and mechanical tests. ISO 13061-2. 2014. ISO: Geneva, Switzerland.

ISO. 2014. Physical and mechanical properties of wood - Test methods for small clear wood specimens - Part 3: Determination of ultimate strength in static bending. ISO 13061-3. 2014. ISO: Geneva, Switzerland.

ISO. 2014. Physical and mechanical properties of wood - Test methods for small clear wood specimens Part 4: Determination of modulus of elasticity in static bending. ISO 13061-4. 2014. ISO: Geneva, Switzerland.

ISO. 2014. Physical and mechanical properties of wood - Test methods for small clear wood specimens Part 17: Determination of ultimate stress in compression parallel to grain. ISO 13061-17. 2014. ISO: Geneva, Switzerland.

ISO. 2011. Buildings and constructed assets-Service life planning - Part 1: General principles and framework. ISO 15686-1. 2011. ISO: Geneva, Switzerland.

Ives, E. 2001. A Guide to Wood Microtomy: Making Quality Microslides of Wood Sections. Ipswich, United Kingdom. ISBN-10: 0954055101.

Kačík, F.; Šmíra, P.; Kačíková, D.; Reinprecht, L.; Nasswettrova, A. 2014. Chemical changes in fir wood from old buildings due to ageing. Cell Chem Technol 48(1-2): 79-88. http://www.cellulosechemtechnol. ro/pdf/CCT1-2(2014)/p.79-88.pdf

Kránitz, K.; Sonderegger, W.; Bues, C.T.; Niemz, P. 2016. Effects of aging on wood: a literature review. Wood Sci Technol 50(1): 7-22. https://doi.org/10.1007/s00226-015-0766-0

Liu, X.Y.; Timar, M.C.; Varodi, A.M.; Sawyer, G. 2017. An investigation of accelerated temperature-induced ageing of four wood species: colour and FTIR. Wood Sci Technol 51(2): 357-378. https://doi.org/10.1007/s00226-016-0867-4

Machado, J.S.; Pereira, F.; Quilhó, T. 2019. Assessment of old timber members: Importance of wood species identification and direct tensile test information. Constr Build Mater 207: 651-660. https://doi.org/10.1016/j.conbuildmat.2019.02.168

Madhoushi, M. 2016. Species and mechanical strengths of wood members in a historical timber building in Gorgan (North of Iran). BioResources 11(2): 5169-5180. https://doi.org/10.15376/biores.11.2.5169-5180

Marchessault, R.H.; Liang, C.Y. 1962. The infrared spectra of crystalline polysaccharides. VIII. Xylans. J Polym Sci 59(168): 357-378. https://doi.org/10.1002/pol.1962.1205916813

Matsuo, M.; Yokoyama, M.; Umemura, K.; Sugiyama, J.; Kawai, S.; Gril, J.; Kubodera, S.; Mitsutani, T.; Ozaki, H.; Sakamoto, M.; Imamura, M. 2011. Aging of wood: Analysis of color changes during natural aging and heat treatment. Holzforschung 65(3): 361-368. https://doi.org/10.1515/hf.2011.040

Merev, N. 1998. Doğu Karadeniz Bölgesindeki Doğal Angiospermae Taksonlarının Odun Anatomisi, Trabzon, Türkiye: KTÜ Basımevi, Genel Yayın No: 189, Fakülte Yayın No: 27: 108-115.

Merev, N. 2003. Odun Anatomisi ve Odun Tanıtımı, Trabzon, Türkiye: KTÜ Basımevi, ISBN: 975-698330-2, pp. 127-128. 
Mohebby, B. 2008. Application of ATR infrared spectroscopy in wood acetylation. J Agr Sci Technol 10(3): 253-259. https://www.sid.ir/en/journal/ViewPaper.aspx?id=108201

Müller, G.; Schöpper, C.; Vos, H.; Kharazipour, A.; Polle, A. 2009. FTIR-ATR spectroscopic analyses of changes in wood properties during particle-and fibreboard production of hard-and softwood trees. BioResources 4(1): 49-71. https://bioresources.cnr.ncsu.edu/BioRes 04/BioRes 0410049 Muller_SVKP FTIR ATR_Anal_Particlebd_Fiberbd_HW_SW_366.pdf

Nilsson, T.; Rowell, R. 2012. Historical wood-structure and properties. J Cult Herit 13(3): S5-S9. https://doi.org/10.1016/j.culher.2012.03.016

Panshin, A.J.; Zeeuw, C. 1970. Textbook of Wood Technology. Volume I, McGraw-Hill, Inc.: United States of America, ISBN: 07-048440-6.

Sonderegger, W.; Kránitz, K.; Bues, C.T.; Niemz, P. 2015. Aging effects on physical and mechanical properties of spruce, fir and oak wood. J Cult Herit 16(6): 883-889. https://doi.org/10.1016/j.culher.2015.02.002

Sousa, H.S.; Branco, J.M.; Lourenço, P.B. 2014. Characterization of cross-sections from old chestnut beams weakened by decay. Int J Archit Herit 8(3): 436-451. https://doi.org/10.1080/15583058.2013.826303

Stefke, B.; Windeisen, E.; Schwanninger, M.; Hinterstoisser, B. 2008. Determination of the weight percentage gain and of the acetyl group content of acetylated wood by means of different infrared spectroscopic methods. Anal Chem 80(4): 1272-1279. https://doi.org/10.1021/ac7020823

Tarmian, A.; Mastouri, A. 2019. Changes in moisture exclusion efficiency and crystallinity of thermally modified wood with aging. iForest 12(1): 92-97. https://doi.org/10.3832/ifor2723-011

Thaler, N.; Humar, M. 2013. Performance of oak, beech and spruce beams after more than 100 years in service. Int Biodeter Biodegr 85: 305-310. https://doi.org/10.1016/j.ibiod.2013.08.020

Thaler, N.; Žlahtič, M.; Humar, M. 2014. Performance of recent and old sweet chestnut (Castanea sativa) wood. Int Biodeter Biodegr 94: 141-145. https://doi.org/10.1016/j.ibiod.2014.06.016

Tintner, J.; Smidt, E.; Tieben, J.; Reschreiter, H.; Kowarik, K.; Grabner, M. 2016. Aging of wood under long-term storage in a salt environment. Wood Sci Technol 50(5): 953-961. https://doi.org/10.1007/s00226-016-0830-4

Uçar, G.; Meier, D.; Faix, O.; Wegener, G. 2005. Analytical pyrolysis and FTIR spectroscopy of fossil Sequoiadendron giganteum (Lindl.) wood and MWLs isolated hereof. Holz Roh Werkst 63(1): 57-63. https://doi.org/10.1007/s00107-004-0530-x

Vurdu, H.; Kesik, H.İ.; Kurtuluș, O.Ç.; Özkan, O.E. 2013. Some physical and mechanical properties of antique and fresh cut Pinus sylvestris and Abies nordmanniana subsp. bornmulleriana woods. Pro Ligno 9(4): 562-567.http://www.proligno.ro/en/articles/2013/4/Vurdu_final.pdf

Wheeler, E.A.; Baas, P.; Gasson, P.E. 1989. IAWA list of microscopic features for hardwood identification. IAWA Bull 10(3): 219-332. https://www.iawa-website.org/uploads/soft/Abstracts/IAWA\%20list $\% 20$ of $\% 20$ microscopic $\% 20$ features $\% 20$ for $\% 20$ hardwood $\% 20$ identification.pdf

Williams, R.S. 2005. Weathering of wood. In Handbook of wood chemistry and wood composites. Rowell, R.M. (ed.). Taylor and Francis CRC Press: Boca Raton, Florida, USA. Volume 7, pp. 142-178.

Yokoyama, M.; Gril, J., Matsuo, M.; Yano, H.; Sugiyama, J.; Clair, B.; Kubodera, S.; Mistutani, T.; Sakamoto, M.; Ozaki, H.; Imamura, M.; Kawai, S. 2009. Mechanical characteristics of aged Hinoki wood from Japanese historical buildings. C R Phys 10(7): 601-611. https://doi.org/10.1016/j.crhy.2009.08.009

Yorur, H.; Kurt, S.; Yumrutas, I. 2014. The effect of aging on various physical and mechanical properties of scotch pine wood used in construction of historical Safranbolu houses. Drvna Ind 65(3): 191-196. https://doi.org/10.5552/drind.2014.1328 